Journal Universitas Muhammadiyah Gresik Engineering, Social Science, and Health International Conference (UMGESHIC)

UMGCINMATIC : $1^{\text {st }}$ Rethinking Education during Covid-19 Era: Challange and Innovation

\title{
IMPLEMENTATION OF PROBLEM BASED LEARNING MODEL ON LEARNING OUTCOMES OF COOPERATION MATERIALS IN CLASS III DIVERSITY AT MINU BANAT MANYAR (STUDY EX POST FACTO)
}

\author{
Author \\ Yusriya Ina's, Ismail Marzuki, Iqnatia Alfiansyah \\ Universitas Muhammadiyah Gresik \\ yusriyainas@gmail.com, ismailmarzuki@umg.ac.id,iqnatia@umg.ac.id
}

\begin{abstract}
This study aims to determine the learning outcomes of cooperation in diversity for third grade students of MINU Banat Manyar for the academic year 2019/2020 by using a problem-based learning model. Based on the results of interviews and observations that show 14 of 29 students have an achievement value below the KKM. This achievement was obtained by students when using the lecture learning method, learning outcomes produced due to a boring classroom atmosphere that can cause students to lack focus in learning, Therefore, the teacher tries to convey the same material in a different way, namely by providing repetition of the material using a problem-based learning model. The type of research used is ex post facto research method. Where this research is described by Sukardi (2003) that Ex Post Facto research is research that has occurred a series of independent variables, when the researcher begins to make observations on the dependent variable. This research was conducted at MINU Banat Manyar, The subject of this research is the class third students of MINU Banat Manyar, totaling 29 students. Data collection techniques used in this research were interviews, questionnaires, and documentation. Interviews were conducted with classroom teachers, while for the provision of questionnaires given to students, and for the documentation carried out are photos during the research as well as supporting data when this research was conducted. Examples of supporting data such as test instruments that are carried out or given to class III students, where the test instrument is in the form of multiple choice consisting of 10 multiple choice questions, lesson plans, grids, learning outcomes, etc.
\end{abstract}

Keywords: Problem based learning, diversity cooperation.

\section{INTRODUCTION}

Humans basically need education to be a human being who is good in character, and spirited patriotism. According to Triyanto (2014) education is an interesting effort that occurs in humans as an effort to provide experiences in formal, informal, non-formal education, in school, outside of school that aims to optimize individual abilities, so that one day individuals can play an appropriate role. [1] When a human being can play his role appropriately, then what he faces will find it easy to do or be resolved. Man is a social being, which is not separated by other individuals or groups, and cannot live alone, therefore sometimes educated humans must be ready to undergo all the challenges and problems that come suddenly. 


\section{UMGCINMATIC : $1^{\text {st }}$ Rethinking Education during Covid-19 Era: Challange and Innovation}

Volume 1 No 2

One of the skills that must be possessed by learners is the ability to solve problems in cooperation and diversity around them. Based on the results of interviews conducted with teachers stated that in the material of cooperation in diversity carried out by the method of lectures learners obtained an average score that has not reached the standard of completion of the ability of at least 75, namely there are 14 learners from 29 learners. The cause of the problem comes from a class atmosphere that is less pleasant and less conducive, with these conditions can make learners less able to understand the lesson. Then the teacher tries to apply the problem based learning model to the cooperation material in diversity at the time before the midterms are held, in the hope that learners can be enthusiastic in learning, focus and can understand the lesson and get a score above the completion of the minimum criteria.

\section{METHODS}

a. Problem based learning model

According to Nurhayati (2004) the problem based learning model is learning with a constructive approach, because teachers act as problem-givers, dialogue, the initiator of inquiry research and intellectual students.[2] Meanwhile, according to Sumantri (2019) the problem based learning model is a series of learning activities that emphasize the process of solving problems faced by learners naturally. This model can also be used to improve critical thinking skills to learners to solve problems in the real world. So it can be concluded based on experts above said that this problem based learning model is a learning model that can be done in the classroom, by giving problems related to daily life, then learners can solve the problem by group / individual. by solving problems together / individuals can hone the thinking skills of learners in learning materials that are in a way that is sustainable.[3]

b. Learning outcomes

Learning outcomes are a measure or level of success that has been achieved by a learner based on his or her experience gained after conducting an evaluation such as a test. And usually realized with certain values and numbers, and cause cognitive, affective, and psychomotor conversations (Sudjana, 2010).[4] While according to Sani (2019) learning outcomes are changes in behavior or competence (attitudes, knowledge, skills) obtained by students after learning activities. [5]

c. Cooperation in diversity

Cooperation is an activity carried out jointly from various parties, to achieve a common goal (Poerwadarminta, 1985). [6] Abu Ahmadi (2007) also revealed that cooperation is a joint effort of the two more countries to carry out tasks and to achieve the objectives that are cooled by being done together. So according to the experts above it can be concluded that cooperation is a form of social interaction between two or more people. In doing the task and with the same goal, so that the work feels light and quickly resolved."[7]

According to Widodo, Anwari, and Maryanto (2015) The diversity of a nation is based on ethnicity, religion, language, culture. [8] Religions that are recognized in Indonesia itself there are 6, namely, Islam, Protestant Christianity, Hinduism, Buddhism, Confucianism, Catholic not only that diversity in Indonesia there are many more, such as regional songs, regional dances, special foods, typical games, gender, and traditional clothing typical of the region. So it can be concluded that cooperation in diversity is a joint effort of two or more people to do something aimed at solving existing 


\section{UMGCINMATIC : $1^{\text {st }}$ Rethinking Education during Covid-19 Era: Challange and Innovation} Volume 1 No 2

problems without discriminating the security that exists in Indonesia such as nations, religions, races and cultures, so that in such cooperation can run smoothly without obstacles and disputes.

This research is a form of quantitative research with expost facto type of research. According to Sugiyono (2016) quantitative data is data in the form of numbers, or quantitative data that is guessed (scoring).[9] So from this understanding quantitative data is data that has a tendency to be analyzed in a statistical way or technique. The data can be a number or score and is usually obtained using a data collection tool whose answer is a range of scores or questions that are given weights. While expost facto research according to Arikunto (2002) is a study that does not start from scratch, but immediately takes the results. [10] The opinion of Sukardi (2003) explained that Ex Post Facto research is a study in which free variable circuits have occurred, when researchers began to make observations of bound variables. [11] From the opinion of the experts above it can be concluded that ex post facto research is research conducted after an event occurs, and this study does not start the research from scratch but only takes supporting data that has occurred then the data is used / studied in this study.

Considering that researchers intend to examine the learning outcomes of class III learners at MINU BANAT Manyar on cooperation materials in diversity by using problem-based learning models, the data that researchers collect will be concluded in the arrangement of words, requiring calculations.

The design of this study was conducted last year by class III teachers in a structured manner, from this study researchers conducted interviews and data retrieval on classroom teachers. Where the researcher gets answers from the questions that have been made by the researcher to uncover the causative factors that have occurred in the learning outcome. The fact of this research is revealed as is from the data collected and has been carried out by classroom teachers in the form of learning results of daily repeat final value, then supported by other supporting data that this research has actually happened, supporting data or evidence of this research has occurred in the form of RPP, Syllabus, Grid, and problem items.

The subjects in this study were 29 students of class III MINU BANAT Manyar, where the implementation of this research was conducted at MINU BANAT Manyar, when this research was conducted in the gasal semester of the 2019/2020 school year. The data collection techniques used are in the form of interviews, questionnaires and documentation, interviews interviews are conducted to classroom teachers about the learning process and how the atmosphere during learning and the results obtained when learning is completed, while for the provision of questionnaires are done to class III learners about opinions on the material submitted, and the learning process in the classroom. The documentation done is photos when the research and supporting data when this research is done such as the value of learning outcomes, rpp, syllabus, etc.

\section{a. To determine the final value of each learner value obtained}

$$
\text { value }=\frac{\text { value obtained }}{\text { maximum score }} \times 100
$$

(Arikunto, 2006:134)

A student is said to be successful if he gets a score above minimum completion criteria which is 75 , which is in accordance with the standard minimum completion criteria in MI BANAT Manyar. 


\section{b. To determine the completion of classical learning}

$$
\text { Classic finish }=\frac{\text { Completed students }}{\text { Number of all students }} \times 100 \%
$$

(Arikunto, 2006:134)

Assessment of learning outcomes is said to be completed classically when it reaches $75 \%$ of the number of learners who reach the value of KKM 75. The criteria for success in students in cognitive ability in learning can be seen in the table below[12]:

Table 1. Classical learning completion criteria

\begin{tabular}{|l|l|}
\hline ercentage of learning completion & \multicolumn{1}{|c|}{ Criterion } \\
\hline $85-100 \%$ & Excellent \\
$75-84 \%$ & Good \\
$60-74 \%$ & Enough \\
$40-59 \%$ & Less \\
$0-39 \%$ & Very lacking \\
\hline
\end{tabular}

\section{c. Analysis of learners' response questionnaires}

At each questionnaire will be asked several questions that are in accordance with the indicators that have been made in accordance with the problem to be examined, so as to describe the problem that will be revealed. Score 1 for the answer "yes" and a score of 0 for the answer "no". The calculation of the response questionnaire of learners in a class can be done by calculating using the following formula:

$$
\text { persentase angket: } \frac{f}{n} X 100 \%
$$

Information:

$f=$ Frequency

$n=$ Many respondents

Tabel 2. Angket Assessment Criteria

\begin{tabular}{|l|l|}
\hline Percentage & Criterion \\
\hline $96-100 \%$ & Very good \\
$71-95 \%$ & Good \\
$55-70 \%$ & Enough \\
$<54 \%$ & Less \\
\hline
\end{tabular}

Source: Bayu Cipta Nugraha [13] 


\section{RESULT AND DISCUSSION}

Based on research that has been done by researchers, the results of the study are obtained as follows.

\section{a. Analysis of Interview Data with Teachers}

Table 3. Analysis of Interview Data with Teachers

\begin{tabular}{|c|c|c|c|c|}
\hline NO & Variable & Indicator & Question & Answer \\
\hline \multirow[t]{3}{*}{1} & \multirow[t]{3}{*}{$\begin{array}{l}\text { Role of } \\
\text { teacher }\end{array}$} & $\begin{array}{l}\text { Know the } \\
\text { condition } \\
\text { of the class }\end{array}$ & $\begin{array}{l}\text { 1. What problems do } \\
\text { students often face } \\
\text { when classroom } \\
\text { learning takes place? } \\
\text { 2. How many students } \\
\text { were in class III last } \\
\text { year? } \\
\text { 3. How much KKM is } \\
\text { there in this school for } \\
\text { theme learning? }\end{array}$ & $\begin{array}{l}\text { 1. The problem in class III is that } \\
\text { students do not understand some of } \\
\text { the material, the lack of focus of } \\
\text { learners is also in the classroom. } \\
\text { 2. } 29 \text { female learners } \\
\text { 3. for learning the theme in class } 3 \text {, } \\
\text { the KKM is } 75\end{array}$ \\
\hline & & $\begin{array}{ll}\text { 2. } & \text { Give an } \\
& \text { evaluation }\end{array}$ & $\begin{array}{l}\text { 9. How to do it for the } \\
\text { evaluation stage, does } \\
\text { you give training } \\
\text { questions or how? } \\
\text { 10. From the evaluation are } \\
\text { many learners who } \\
\text { have complete value in } \\
\text { learning? }\end{array}$ & $\begin{array}{l}\text { 9. For the evaluation stage yes I give } \\
\text { questions, namely the question of } \\
\text { multiple choices first, only for the } \\
\text { next few meetings with the same } \\
\text { material I give the problem of } \\
\text { essays to learners } \\
\text { 10. 10. For this evaluation stage, some } \\
\text { learners have experienced } \\
\text { completion in learning in this } \\
\text { material. And some of the } \\
\text { still unfinished possibilities due to } \\
\text { other factors, and will be additional } \\
\text { value tone and additional guidance so } \\
\text { that learners can understand the } \\
\text { material like other friends. }\end{array}$ \\
\hline & & $\begin{array}{l}\text { 11. Giving } \\
\text { guidance }\end{array}$ & $\begin{array}{l}\text { 11. What if there are still } \\
\text { students who have difficulty } \\
\text { in learning? }\end{array}$ & $\begin{array}{l}\text { 11. Usually if there are learners who } \\
\text { have not been able to, I provide my } \\
\text { own guidance after school learning } \\
\text { is over, so that the learners are not } \\
\text { left behind by their classmates. }\end{array}$ \\
\hline 2. & $\begin{array}{l}\text { Learning } \\
\text { model }\end{array}$ & 1. Model used & $\begin{array}{l}\text { 4. What learning model is } \\
\text { used for cooperation } \\
\text { material in diversity on the } \\
\text { theme of } 3 \text { subthema } 4 \text { ? } \\
8 \text {. Is there any difficulty if } \\
\text { this model is applied to }\end{array}$ & $\begin{array}{l}\text { 4. 4. initially I tried to use a method } \\
\text { that is only a lecture, but because } \\
\text { many learners are not yet } \\
\text { complete, when there is still time } \\
\text { on the sidelines of the midterms, I }\end{array}$ \\
\hline
\end{tabular}


UMGCINMATIC : $1^{\text {st }}$ Rethinking Education during Covid-19 Era: Challange and Innovation Volume 1 No 2

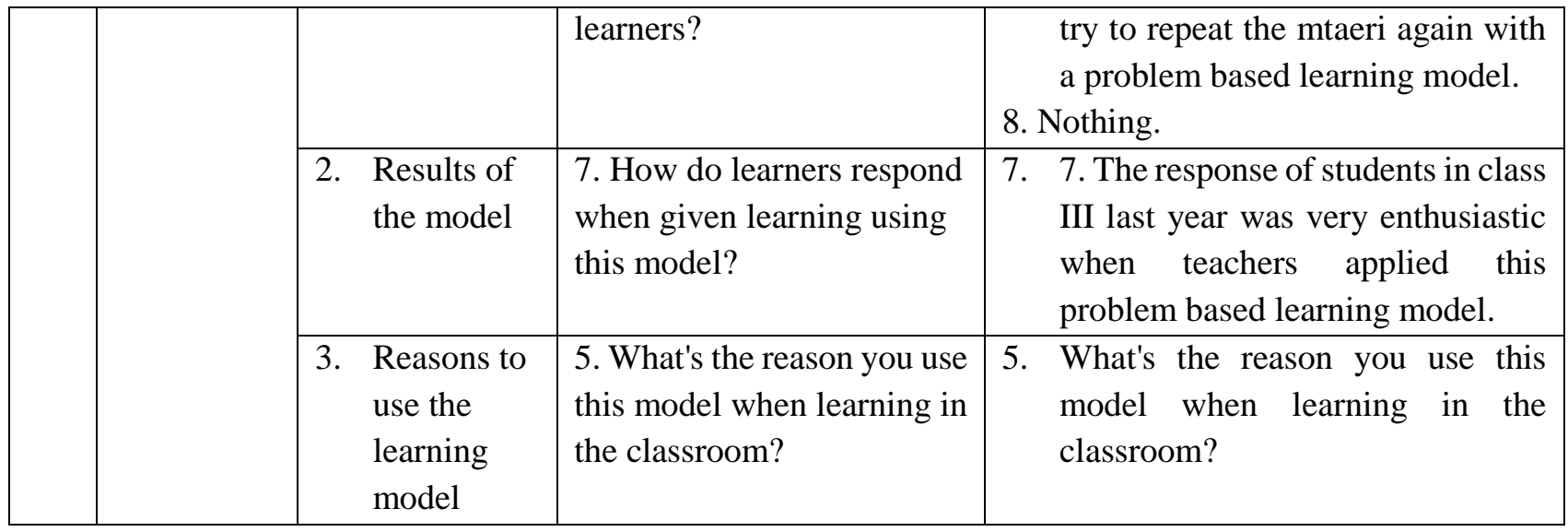

\section{b. Data Analysis of Questionnaires and interviews with Learners}

Researchers have submitted 8 items of statement to respondents. To calculate the value and analysis of data, in the study used a score of 1 when answering "yes" and a score of 0 when answering "no". The statement was to find out the respondents' responses about the implementation of problem based learning models to the results of learning cooperation materials in the diversity of class III learners at MINU Banat Manyar.

This questionnaire is useful to obtain data and then will be processed or processed, the results of the answers of class III MINU Banat Manyar respondents who numbered 29 learners were further recapitulation in the table and analyzed with the following formula percentage:

Formula: $\mathrm{P}=\mathrm{F} / \mathrm{N}$ x $100 \%$

Description:

$\mathrm{P}=$ Percentage

$\mathrm{F}=$ Frequency / number of respondents: number of respondents

Table 4. Data Analysis of Questionnaires and interviews with Learners

\begin{tabular}{|c|c|c|c|c|c|c|}
\hline \multirow[t]{2}{*}{ No } & \multirow[t]{2}{*}{ Variable } & \multirow[t]{2}{*}{ Indicator } & \multirow[t]{2}{*}{ Question } & \multicolumn{2}{|c|}{$\begin{array}{c}\text { Total students } \\
\text { answering } \\
\text { yes/no }\end{array}$} & \multirow[t]{2}{*}{ Reason } \\
\hline & & & & Yes & No & \\
\hline 1 & $\begin{array}{l}\text { Learning } \\
\text { Model }\end{array}$ & $\begin{array}{l}\text { 1. Classroom } \\
\text { atmosphere }\end{array}$ & $\begin{array}{l}\text { 1. What was the } \\
\text { atmosphere of the } \\
\text { class when you } \\
\text { were class III } \\
\text { yesterday, was it } \\
\text { fun or not? }\end{array}$ & 29 & 0 & $\begin{array}{l}\text { 1. Almost all } \\
\text { respondents to class } \\
\text { III MINU BANAT } \\
\text { Manyar stated } \\
\text { "yes" which means } \\
\text { that they are happy } \\
\text { in the atmosphere } \\
\text { of learning in class } \\
\text { III in 2019, the } \\
\text { average reason is to }\end{array}$ \\
\hline
\end{tabular}




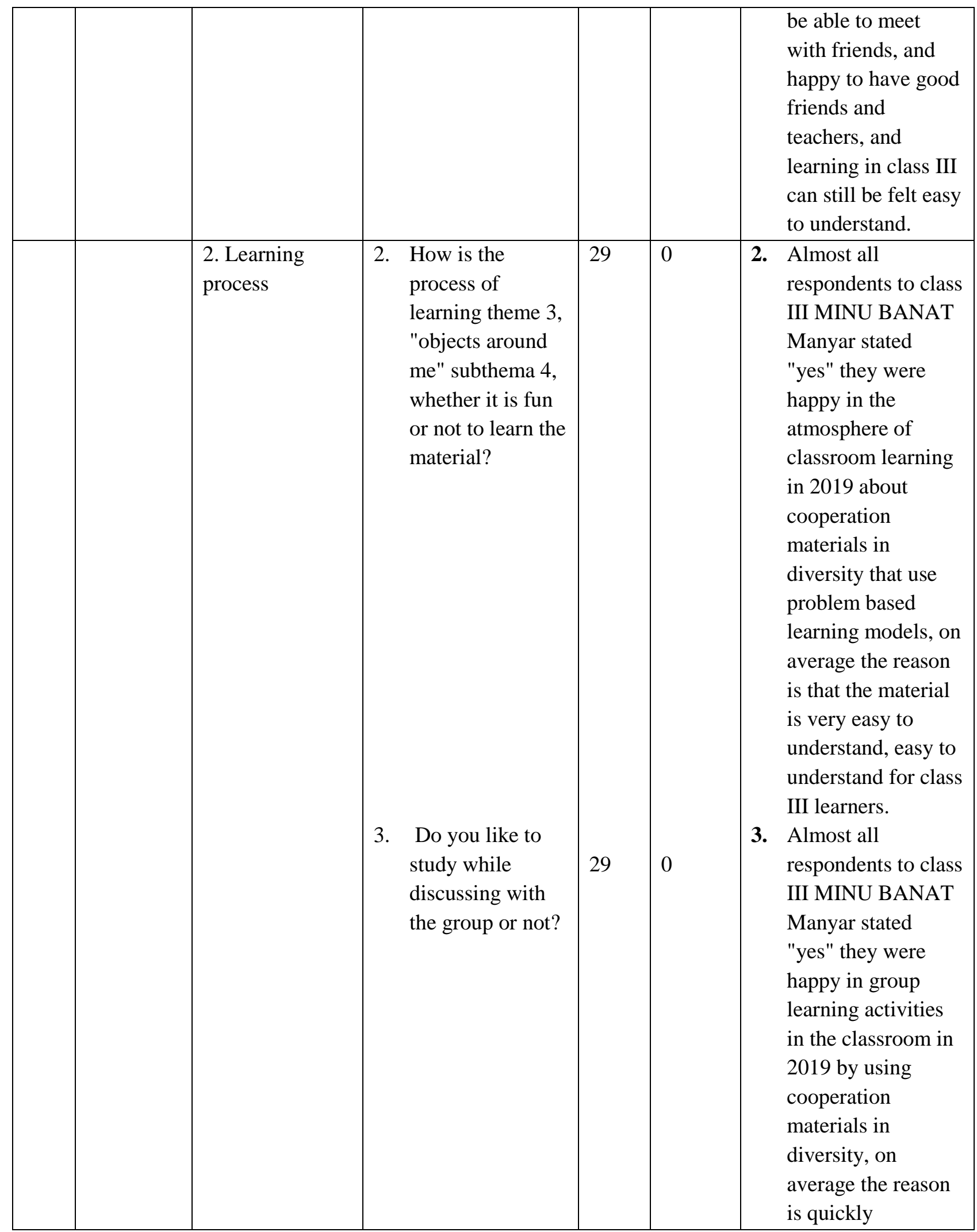


UMGCINMATIC : $1^{\text {st }}$ Rethinking Education during Covid-19 Era: Challange and Innovation Volume 1 No 2

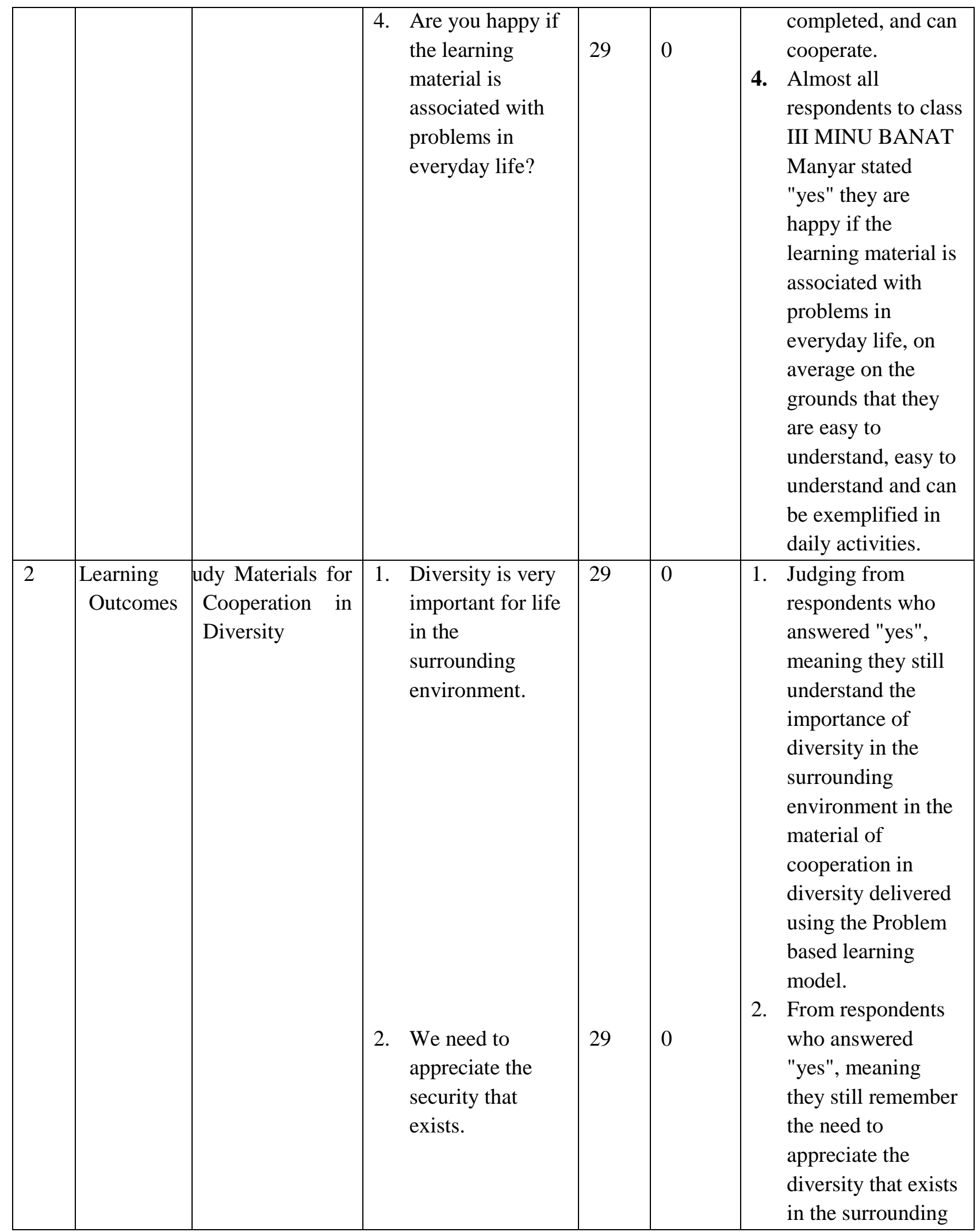




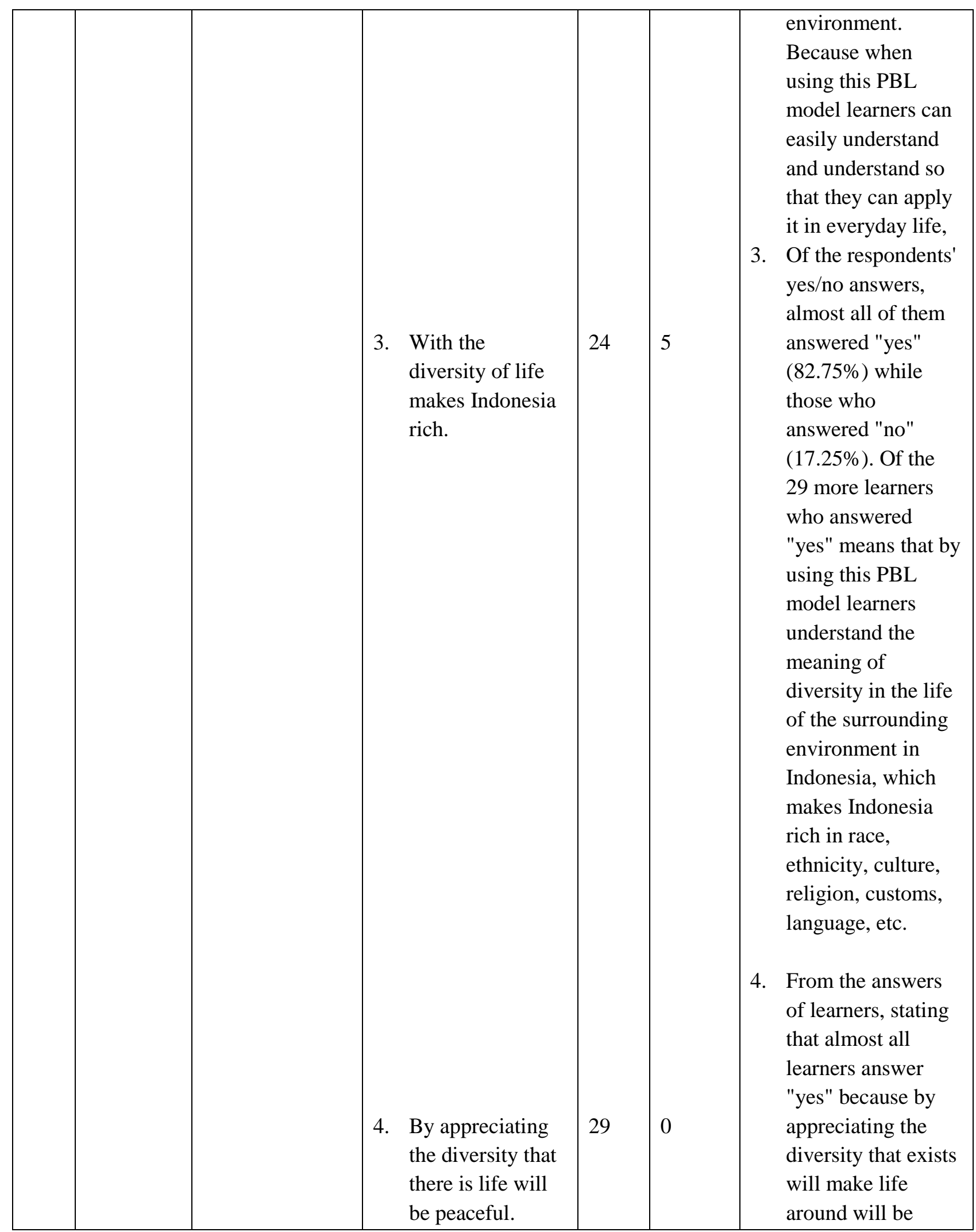




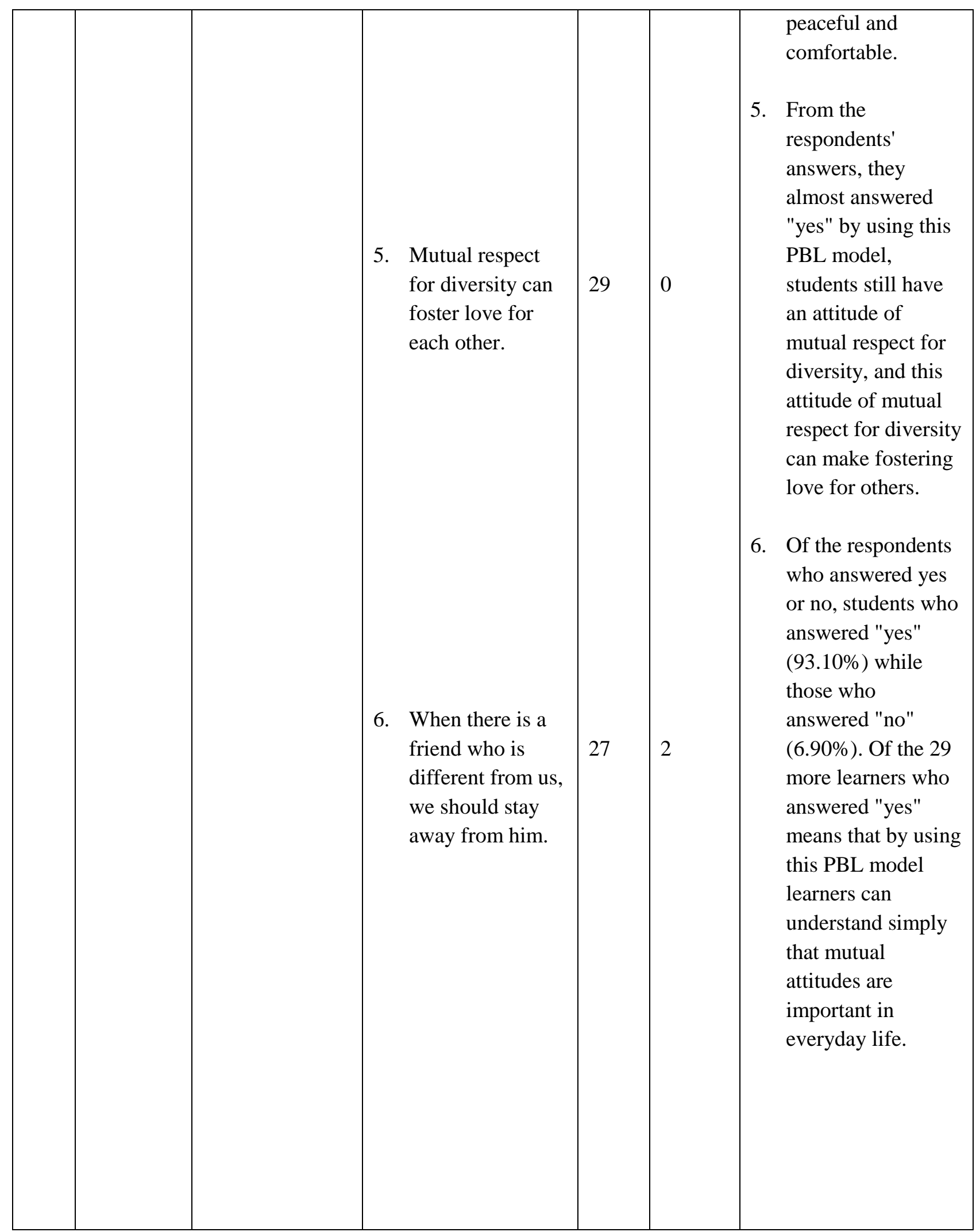


UMGCINMATIC : $1^{\text {st }}$ Rethinking Education during Covid-19 Era: Challange and Innovation Volume 1 No 2

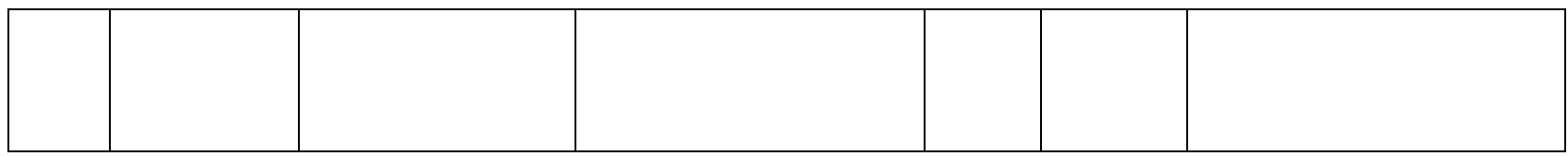

\section{c. Data and research results}

The data obtained in this study is in the form of value data that has been done by classroom teachers when daily repeats take place in the 2019/2020 school year with an early stage that uses the lecture method and the second stage using the problem based learning model. The initial stage when using this lecture method presentation of learning results obtained by learners from class III teacher MINU Banat Manyar can be seen in the table below:

Table 5. Learning outcomes with lecture methods

\begin{tabular}{|l|l|l|l|}
\hline NO & Student Name & $\begin{array}{c}\text { Value } \\
\text { PPKn }\end{array}$ & Information \\
\hline 1 & AN & 60 & NC \\
\hline 2 & AFG & 70 & NC \\
\hline 3 & AM & 70 & NC \\
\hline 4 & AFAZ & 70 & NC \\
\hline 5 & AS & 70 & NC \\
\hline 6 & BKS & 60 & NC \\
\hline 7 & DA & 80 & C \\
\hline 8 & ESS & 70 & NC \\
\hline 9 & FZ & 80 & C \\
\hline 10 & FNTP & 90 & C \\
\hline 11 & FHD & 80 & C \\
\hline 12 & FII & 80 & C \\
\hline 13 & HHR & 70 & NC \\
\hline 14 & IS & 60 & NC \\
\hline 15 & IBA & 70 & NC \\
\hline 16 & KH & 80 & C \\
\hline 17 & MNM & 70 & C \\
\hline 18 & MPN & 80 & C \\
\hline 19 & MZM & 80 & C \\
\hline 20 & MR & 90 & C \\
\hline 21 & NDPP & 70 & C \\
\hline 22 & NRM & 70 & NC \\
\hline 23 & NZP & 80 & C \\
\hline 24 & RO & 80 & C \\
\hline 25 & SMS & 80 & C \\
\hline 26 & SZ & 70 & NC \\
\hline 27 & TAR & 60 & NC \\
\hline & & & \\
\hline
\end{tabular}


UMGCINMATIC : $1^{\text {st }}$ Rethinking Education during Covid-19 Era: Challange and Innovation Volume 1 No 2

\begin{tabular}{|l|l|l|l|}
\hline 28 & WA & 80 & $\mathrm{C}$ \\
\hline 29 & ZCN & 80 & $\mathrm{C}$ \\
\hline Totaling & $\mathbf{2 1 5 0}$ & NC $=\mathbf{1 4}$ \\
\hline Mean & $\mathbf{7 4 , 1 3}$ & \\
\hline & & $\mathbf{C = 1 5}$ \\
\hline $\begin{array}{l}\text { CLASSIC FINISH } \\
\text { PERCENT }\end{array}$ & & \\
\hline
\end{tabular}

Information :

$\mathrm{NC}$

$\mathrm{C}$

: Not Complete

Individual completion : When learners score $>75$ in this daily replay.

Classic completion $\quad$ : If the learners are said to be achieved $>75$ complete of the total class

III learners in one class.

From the table below can be taken the example of one of the students who get all the correct answers from 10 questions that each problem is worth 1, then the value is divided by the maximum score of 10, then multiplied by the number 100, so as to get a value of 100 .

Value $=\frac{\text { score obtained }}{\text { maximum score }} \times 100$

Value $=\frac{1}{10} \times 100=100$

Based on tables 4 and 5 above the completion of learners in the first stage using individual lecture methods is 15 out of 14 learners, and the completion of learners in the second stage by using the problem based learning model individually is 25 learners from 29 learners in class III, then the value obtained, The average, and the percentage of classical completion on learning outcomes obtained in stages 1 and 2 are:

Stage 1:

Classic finish $=\frac{\text { Completed students }}{\text { totalling students }} \times 100 \%$

$$
=\frac{15}{29} \times 100=51,72 \%
$$

Stage 2:

Classic finish $=\frac{\text { Completed students }}{\text { totalling students }} \times 100 \%$

$$
=\frac{25}{29} \times 100=86,20 \%
$$

Based on the table above, the results of the child's cognitive test study at the time of daily replay stages 1 and 2, it can be seen that there are 14 learners who score less than KKM, and there are 15 learners who score above KKM and with the completion of learning in one class obtained is $51.72 \%$. While by using the problem based learning model in stage 2 there are 4 learners still less than the minimum completion criteria, and 25 learners have scored above the minimum completion criteria with the completion of learning obtained in one class is $86.2 \%$. This shows that the percentage of daily repeat implementation that has been done by classroom teachers using the problem based learning model has reached the specified completion standard of $75 \%$. 


\section{CONCLUSION}

Based on the results of research and discussion by applying the Problem Based Learning (PBL) learning model to find out the learning outcomes of learners in cooperation materials in diversity in class III MINU Banat Manyar related to problem formulation and research objectives, it can be concluded that the results of learning cooperation materials in uniform have increased and achieved classical completion at stage 1 , which is $51.72 \%$. This shows that the results of learning cooperation materials in diversity increased by $34.48 \%$ i.e. learners answered questions on the individual evaluation test sheet given, so that the percentage of classical completion reached the specified completion standard of $75 \%$.

\section{REFERENCES}

[1] Triyanto, T. (2014). Pengantar Pendidikan. Jakarta: PT Bumi Aksara.

[2] Nurhayati, A. (2004). Penerapan Problem Based Learning . Jurnal Pendidikan dan Kebudayaan No.51, 834 .

[3] Sumantri, M. S. (2019). Strategi Pembelajaran Teori dan Praktik di Tingkat Pendidikan Dasar. Depok: Rajawali Pers.

[4] Sudjana, N. (2010). Penilaian Hasil Proses Belajar Mengajar. Bandung : PT. Remaja Rosdakarya .

[5] Sani, R. A. (2019). Strategi Belajar Mengajar . Depok : Rajawali Pers.

[6] Poerwadarminta, W. (1985). Kamus Umum Bahasa Indonesia. Jakarta: Balai Pustaka.

[7] Abu Ahmadi. (2007). Sosiologi Pendidikan. Jakarta : Rineka Cipta.

[8] Widodo, W., Anwari, B., \& Maryanto. (2015). PENDIDIKAN KEWARGANEGARAAN PENGANTAR TEORI. Yogyakarta: CV. ANDI OFFSET.

[9] Sugiyono. (2016). Metode Penelitian Kuantitatif,Kualitatif dan R\&D. Bandung: PT Alfabet.

[10] Arikunto Suharsimi. (2002). Penelitian Tindakan Kelas. Jakarta : Rineka Cipta.

[11] Sukardi. (2003). Metodologi Penelitian Pendidikan Kompetensi dan Prakteknya. Jakarta: Bumi Aksara .

[12] Arikunto Suharsimi. (2006). Prosedur Penelitian . Jakarta : Rineka Cipta .

[13] Nugraha, B. C. (2018). Penerapan model pembelajaran problem based learning untuk meningkatkan kerjasama dan hasil belajar siswa kelas iv a pada subtema keberagaman budaya bangsaku. 